\title{
The invasive red alga Gracilaria vermiculophylla in the Baltic Sea: adaptation to brackish water may compensate for light limitation
}

\author{
Florian Weinberger ${ }^{1, *}$, Björn Buchholz ${ }^{1}$, Rolf Karez $^{2}$, Martin Wahl ${ }^{1}$ \\ ${ }^{1}$ Leibniz-Institut für Meereswissenschaften (IFM-GEOMAR), Düsternbrooker Weg 20, 24105 Kiel, Germany \\ ${ }^{2}$ Landesamt für Natur und Umwelt des Landes Schleswig-Holstein, Hamburger Chaussee 25, 24220 Flintbek, Germany
}

\begin{abstract}
The recent introduction of Gracilaria vermiculophylla (Rhodophyta) to the Kiel Fjord area was a reason for concern, since this red macroalga perfoms best under mesohaline conditions and thus appears well adapted to thrive and spread in the Baltic Sea environment. A systematic survey on a coastal range of $500 \mathrm{~km}$ in 2006 and 2007 indicated considerable multiplication and spreading of G. vermiculophylla within Kiel Fjord, but provided little evidence of long-distance transport. Nonetheless, flow-through growth experiments conducted at a range of salinities under ambient light showed that G. vermiculophylla should be able to grow in most of the Baltic Sea. Growth declined only below a salinity of 5.5 . High water temperatures in summer seem to reduce resistance against low salinity. Growth of G. vermiculophylla in the SW Baltic is limited by light and is only possible during summer and above a depth of $3 \mathrm{~m}$. Drifting fragments are dispersed by currents. Either they sink to deeper waters, where they degrade, or they accumulate in shallow and sheltered waters, where they form perennial mats. These overgrow not only soft bottom sediments, but also stones, which are an important habitat to Fucus vesiculosus, the main native perennial alga in the Baltic Sea. As compared to $F$. vesiculosus, $G$. vermiculophylla seems to represent a preferred refuge for mesograzers and other invertebrates, particularly in winter. Nonetheless, feeding trials showed that potential grazers avoided G. vermiculophylla relative to $F$. vesiculosus. Daily biomass uptake by grazers associated with G. vermiculophylla in nature did not exceed $2 \mathrm{~g} \mathrm{~kg}^{-1}$ and is $<11 \%$ of average daily net growth $\left(18.5 \mathrm{~g} \mathrm{~kg}^{-1}\right)$ in the first $2 \mathrm{~m}$ below sea level. Consequently, feeding may not be sufficient to control the spread of G. vermiculophylla in the SW Baltic. Our study suggests that absence of feeding enemies and adaptation to brackish water may allow $G$. vermiculophylla to invade most shallow coastal waters of the inner Baltic Sea despite light limitation.
\end{abstract}

KEY WORDS: Fucus · Gracilaria $\cdot$ Introduced species · Invasion biology $\cdot$ Algal invasion

\section{INTRODUCTION}

The native distribution area of the red macroalga Gracilaria vermiculophylla (Ohmi) Papenfuss is the Northwest Pacific (Tseng \& Xia 1999, Terada \& Yamamoto 2002). During the last 15 yr it has been detected at the North American eastern coast (Freshwater et al. 2006, Thomsen et al. 2006) and western coast (Bellorin et al. 2004), as well as in Europe (Rueness 2005). At the NE Atlantic coast the known distribution area of $G$. vermiculophylla extends in latitude from Morocco (C. Destombe pers. comm.) to SW Sweden $\left(57.7^{\circ} \mathrm{N}\right.$ i Ny- berg 2007). In 2005 the species was detected for the first time east of the Danish Belt at Kiel (Germany, $54.3^{\circ} \mathrm{N}_{i}$ Schories \& Selig 2006).

The invasive success and ecological impact of a species in a new environment cannot be predicted with certainty (Boudouresque \& Verlaque 2002). Nonetheless, certain traits exist that are typical for successful invasive macroalgae (Maggs \& Stegenga 1999, Boudouresque \& Verlaque 2002, Nyberg \& Wallentinus 2005). Nyberg \& Wallentinus (2005) proposed the use of 13 different traits to estimate potential macroalgal dispersal, settlement and ecological impact. Based on 
this method, they placed Gracilaria vermiculophylla among the 4 most potent invaders out of 114 nonindigenous macroalgal species in Europe (Nyberg 2007). Specific traits of G. vermiculophylla that have been considered as indicative of its considerable invasive potential are: a remarkable ability to recruit from spores and grow from fragments (Rueness 2005, Nyberg 2007, Thomsen et al. 2007) and a high tolerance to environmental stress (Yokoya et al. 1999, Rueness 2005, Nyberg 2007). In particular, G. vermiculophylla is highly resistant to low salinities (Yokoya et al. 1999, Raikar et al. 2001, Rueness 2005, Nyberg 2007, Thomsen et al. 2007), and mainly grows in estuaries and brackish water lagoons (Terada \& Yamamoto 2002, Rueness 2005, Freshwater et al. 2006, Thomsen et al. 2007). Resistance to low salinity is an important preadaptation for successful invasion into brackish water seas (Paavola et al. 2005). A strong performance of G. vermiculophylla in the Baltic Sea has therefore been prognosticated (Schories \& Selig 2006, Nyberg 2007, Thomsen et al. 2007).

The Baltic Sea east of the Danish straits is the world's largest brackish water sea without significant tides, but with prolonged periods of high or low water mainly caused by atmospheric fluctuations. The present salinity decreases over a gradient from about 20 at the Danish straits to $<3$ in the innermost Gulfs of Bothnia and Finland (Meier 2006). Salinity in the Baltic Sea is constantly subject to fluctuations, due to changes in precipitation, water exchange with the North Sea, currents and stratification processes (Meier 2006). Mainly due to the reduced salinity and a low geological age of the Baltic Sea, its biological diversity is relatively limited (Paavola et al. 2005). As a consequence, non-indigenous species are generally confronted with fewer competing or antagonistic species than in fully marine conditions. For example, herbivorous urchins are missing and few perennial seaweeds exist. Other characteristics of the Baltic Sea that must be expected to directly affect macroalgal performance are relatively large seasonal fluctuations in water temperature (Meier 2006), scarceness of hard substrata in the western and southern coastal regions (Rönnbäck et al. 2007 ), and its extension in latitude of $>12^{\circ}$, from $53^{\circ} 40^{\prime}$ to $65^{\circ} 50^{\prime} \mathrm{N}$. Resulting from this extension, day length in the northern and southern Baltic Sea differs considerably: the longest day of the year lasts nearly $24 \mathrm{~h}$ at $65^{\circ} 50^{\prime} \mathrm{N}$, but only $17 \mathrm{~h}$ at $53^{\circ} 40^{\prime} \mathrm{N}$. On the other hand, solar radiation is stronger in the southern than in the northern Baltic Sea, resulting in similar total input of sun light in summer, but higher input in the southern Baltic Sea in winter (Chandler et al. 2004).

Here, we report on the recent distribution and spreading velocity of Gracilaria vermiculophylla along the German Baltic coast and on its growing capacity and loss to grazers in this region. We also estimate its potential for further spread, taking into consideration the specific conditions of the inner Baltic. We present results of growth experiments, suggesting that G. vermiculophylla may cope with the light regime and salinity conditions in large parts of the Baltic, profit from lack of grazers and spread to more northward latitudes than in its natural distribution range or in fully marine conditions. We also present first evidence that G. vermiculophylla has the capacity to accelerate the decline of Fucus vesiculosus - previously the main habitatforming macroalga in the Baltic Sea (Rönnbäck et al. 2007) - in sheltered coastal regions. On the other hand, we also show that $G$. vermiculophylla provides a new habitat - comparably or more attractive than $F$. vesiculosus - to various seaweed-associated animals.

\section{MATERIALS AND METHODS}

Distribution of Gracilaria vermiculophylla. In order to identify preferred habitats and to quantify the spreading velocity of G. vermiculophylla, its distribution was monitored in 2 consecutive years (2006 and 2007). For this purpose, approximately $1 \mathrm{~km}$ long beach sections that were located in distances of approximately $10 \mathrm{~km}$ were browsed on a coastal range of approximately $500 \mathrm{~km}$ between Glücksburg (54 50' N, $\left.9^{\circ} 31^{\prime} \mathrm{E}\right)$ and Warnemünde $\left(54^{\circ} 10^{\prime} \mathrm{N}, 12^{\circ} 03^{\prime} \mathrm{E}\right)$. Areas where G. vermiculophylla was detected on the beach were investigated further by boat, using an aquascope in shallow water and a video system in selected deep water areas. The taxonomy of Gracilaria and related genera is notoriously difficult, but material from the Kiel area has been identified as G. vermiculophylla based upon DNA sequencing (Schories \& Selig 2006), and from the Baltic Sea east of the Belt no other Gracilariaceae have been reported (Nielsen et al. 1995). Morphologically similar native Gracilariaceae (Gracilaria gracilis or Gracilariopsis longissima) from the North Sea do not tolerate the salinity conditions in Kiel Fjord (authors' unpubl. obs.).

Growth capacity in the sea. A growth experiment with Gracilaria vermiculophylla was conducted from the end of May 2006 to the end of June 2007 in the sea in order to investigate water depth and seasonal effects upon growth. G. vermiculophylla was collected in Kiel-Wik (54 $\left.21^{\prime} 11^{\prime \prime} \mathrm{N}, 10^{\circ} 08^{\prime} 29^{\prime \prime} \mathrm{E}\right)$. Incubation in the sea was conducted in standardized net bags of polypropylene with a mesh size that allowed mesograzers to enter the bags (Novanet Kunststoff, maximum length: $20 \mathrm{~cm}$, maximum width: $10 \mathrm{~cm}$, mesh width: $9 \mathrm{~mm}$ ). For exposure in the sea, the net bags were attached at a distance of $3 \mathrm{~km}$ from the collection site to 6 vertical ropes at $0.25,0.5,1,2,3,4$ and $5 \mathrm{~m}$ 
below mean sea surface level, representing the full depth range in which $G$. vermiculophylla may be detected in the Kiel Fjord. The bags were initially filled with $10 \mathrm{~g}$ fresh weight (FW) of G. vermiculophylla, and growth was quantified by biweekly weight measurements (FW1, FW2). Growth was calculated as (FW2 FW1 $\times \mathrm{FW}^{-1} \times$ incubation time ${ }^{-1}$. After each measurement, the algal fresh weight was readjusted to $10 \mathrm{~g}$. On these occasions, the net bags were replaced when they were covered by fouling organisms, in order to prevent shading. Linear correlations of $G$. vermiculophylla growth during biweekly time intervals with the prevailing water temperature, photosynthetically active radiation (PAR) and solar radiation (SR) were calculated, while iterative adaptation of a logistic doseresponse function using the Prism 4 software package (GraphPad Software) allowed the identification of SR doses that were required to support growth directly below the water surface.

In addition to the biweekly growth measurements, the photosynthetic capacity of Gracilaria vermiculophylla adapted to different water depths was measured in 3 mo intervals by pulse-amplitude-modulated fluorometry, in order to estimate the algal capacity to adapt to sudden changes in light exposure, using a Diving-PAM (Walz) underwater fluorometer. Upon the application of a saturating flash $\left(21000 \mu \mathrm{mol} \mathrm{m} \mathrm{m}^{-2} \mathrm{~s}^{-1}\right.$ for $1 \mathrm{~s})$, the rise in tissue fluorescence from the base value $\left(F_{\mathrm{o}}\right)$ to the maximum value $\left(F_{\mathrm{m}}\right)$ was quantified. Light saturation fully reduces the first electron acceptor of photosystem II (PSII) and the quantum efficiency of PSII primary photochemistry is therefore given by $F_{\mathrm{v}} / F_{\mathrm{m}}=\left(F_{\mathrm{m}}-F_{\mathrm{o}}\right) / F_{\mathrm{m}}$, where $F_{\mathrm{v}}$ is maximum variable fluorescence. Adaptation to darkness for $10 \mathrm{~min}$ prior to the measurement allowed for quantification of the maximal quantum yield, while measurement during sunlight exposure allowed for quantification of the real quantum yield in steady state.

Abiotic data. Results obtained during the growth experiment were examined for correlation with hydrographic and meteorological parameters of the inner Kiel Fjord. Data for sea surface level, water temperature and SR (300 to $2800 \mathrm{~nm}$ ) were kindly provided by the Marine Meteorology Department of IFM-GEOMAR in intervals of $8 \mathrm{~min}$ for the whole period of the experiment. PAR (400 to $700 \mathrm{~nm}$ ) was measured using a LI192 quantum sensor connected to a LI1400 data logger (Li-Cor). Simultaneous measurement of PAR and SR during 2 time periods in June 2005 and November 2005 allowed the development of a mathematical model that extrapolates PAR from SR with sufficient accuracy (Fig. 1). Long-term input of PAR above the sea surface could in this way be estimated from longterm input of SR. Depth profiles of PAR attenuation in the water column were measured in biweekly to

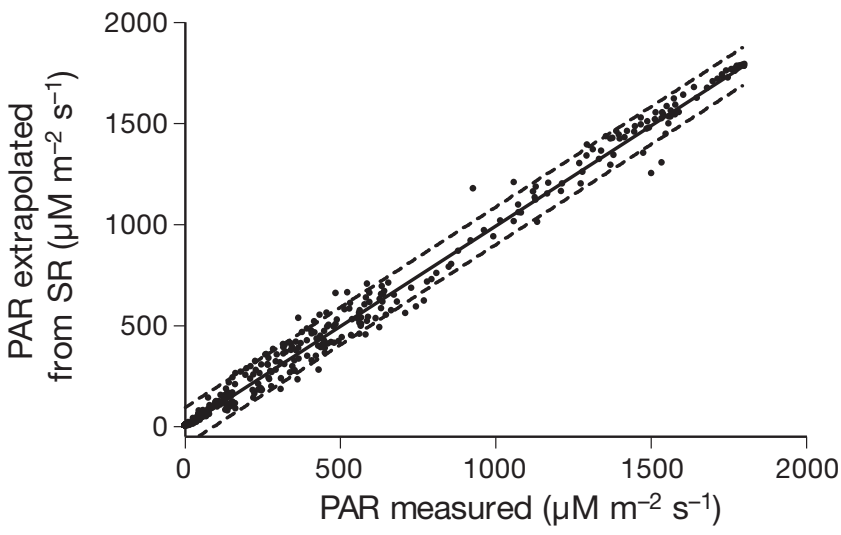

Fig. 1. Correlation of photosynthetically active radiation (PAR, 400 to $700 \mathrm{~nm}$ ) measured and PAR extrapolated from solar radiation (SR, 300 to $2800 \mathrm{~nm}$ ) measured. Line represents the best fitting linear function $\left(\mathrm{r}^{2}=0.992, \mathrm{p}<0.0001\right)$, dotted lines indicate the $95 \%$ prediction interval

monthly time intervals and used to estimate the longterm input of PAR below the sea surface at different water depths.

Growth capacity at low salinities. The capacity of Gracilaria vermiculophylla to grow at different salinities - usually in batch cultures and under laboratory conditions - has repeatedly been investigated (Yokoya et al. 1999, Raikar et al. 2001, Rueness 2005, Nyberg 2007, Thomsen et al. 2007), and it was the purpose of our experiments to simulate more natural conditions, including continuous water exchange, oscillating salinities and grazing. For this purpose, aquaria containing $25 \mathrm{l}$ of water with a depth of $0.1 \mathrm{~m}$ were used and exposed to ambient light in 3 successive experiments that were conducted in spring, summer and autumn 2007. The flow-through rate was $21 \mathrm{~min}^{-1}$. In order to obtain different salinities seawater from the inner Kiel Fjord was mixed with non-chlorinated tap water in different ratios, so that the final salinity was approximately 80,60, 40, 20 and $5 \%$ of the Kiel Fjord salinity (13 to 17). Each salinity was tested in 2 aquaria, each of which contained 6 net bags with G. vermiculophylla. Algal origin and the methodology of growth measurement were as in the experiment conducted in the sea. Salinities were monitored regularly with a conductometer (Cond 315i, WTW GmbH), and water temperatures were continuously logged (Pendant Temp/ Light, HOBO). In order to guarantee sufficient nutrient supply at all salinities, fertilizer (Hakaphos Gartenfreund, Compo) was added every 15 min from a stock solution $\left(1 \%\right.$ in $\left.\mathrm{H}_{2} \mathrm{O}\right)$ to the incoming sea- and tapwater, using a dosing pump (Dupla Alpha, Dohse Aquaristik $\mathrm{KG}$ ). In this way, average medium concentrations of $1.8 \mu \mathrm{M} \mathrm{NO}_{3}{ }^{2-}, 8.2 \mu \mathrm{M} \mathrm{NH}_{4}{ }^{+}, 1 \mu \mathrm{M} \mathrm{PO}_{4}{ }^{3-}$ and $9 \mathrm{nM}$ $\mathrm{Fe}^{2+/ 3+}$ were maintained. Grazers originating from the Kiel Fjord were added to G. vermiculophylla at the be- 
ginning of each experiment at the densities that were associated with the alga in nature (5 to 15 Idotea balthica Pallas, 2 to 4 Littorina sp., 3 to 19 Gammarus sp.). Densities of associated organisms were determined as described below. Prior to each experiment, G. vermiculophylla and grazers were adapted stepwise over $1 \mathrm{wk}$ to reduced salinities. Growth observed at different salinities in a given time period was tested for significant differences $(\mathrm{p}=0.05)$ using Kruskal-Wallis ANOVA and the Nemenyi post hoc test.

Growth capacity at different light intensity/day length combinations. Overall light input in summer is similar in the northern and southern Baltic, while light intensity and day length regime vary considerably. An experiment was therefore conducted in order to investigate possible effects of different combinations of day length and light intensity upon Gracilaria vermiculophylla growth. Aquaria were incubated in a constant temperature room of $15^{\circ} \mathrm{C}$ and continuously provided with filtered seawater $\left(21 \mathrm{~min}^{-1}\right)$. They were protected from unwanted light with black plastic foil and either maintained in darkness or exposed to artificial light for $6,8,12$, or $24 \mathrm{~h} \mathrm{~d}^{-1}$. Light was provided by 4, 3, 2 and 1 fluorescent lamps (Triplus $450 \mathrm{~mm}$ 15W, Interpet), respectively, and each lamp provided approximately $110 \mu \mathrm{mol} \mathrm{m} \mathrm{m}^{-2} \mathrm{~s}^{-1}$. In this way, G. vermiculophylla was exposed to similar daily doses of PAR in all light treatments $\left(9.5 \mathrm{~mol} \mathrm{~m}^{-2} \mathrm{~d}^{-1}\right)$. Algal origin and the methodology of growth measurement were as in the experiment conducted in the sea, with 6 net bags aquarium ${ }^{-1}$. Growth observed at different salinities in a given time period was tested for significant differences $(p=0.05)$ using Kruskal-Wallis ANOVA and the Nemenyi post hoc test.

Quantification of associated animals. For the quantification of animals that were associated with Gracilaria vermiculophylla and Fucus vesiculosus, 5 algal individuals (between 50 and $150 \mathrm{~g}$ fresh weight) were collected at Kiel-Wik (54 $\left.21^{\prime} 11^{\prime \prime} \mathrm{N}, 10^{\circ} 08^{\prime} 29^{\prime \prime} \mathrm{E}\right)$ in shallow water in a net (mesh size: $0.1 \mathrm{~mm}$ ) and fixed in seawater containing formaldehyde $(4 \%)$. The algae were then systematically browsed and associated animals were identified according to Bick \& Gosselck (1985), Jagnow \& Gosselck (1987) and Köhn \& Gosselck (1989) and counted. Feeding habits of all taxa were drawn from the same literature. Complete quantifications were conducted in February 2006, June 2006 and February 2007, in order to cover aspects during a normal winter, during summer and during an extremely mild winter, respectively. A nonparametric 2-way ANOVA according to Sheirer-Ray-Hare (Dytham 2005) was conducted in order to detect significant effects of season and alga upon the diversity and density of associated organisms. Additional quantifications of potential main mesograzers on G. vermiculophylla were conducted prior to growth experiments at reduced salinities (see above).

Feeding experiments. The susceptibility of Gracilaria vermiculophylla and Fucus vesiculosus to selected herbivores and omnivores was investigated in feeding trials. Both algae and grazers were collected in Kiel-Wik (54 $\left.21^{\prime} 11^{\prime \prime} \mathrm{N}, 10^{\circ} 08^{\prime} 29^{\prime \prime} \mathrm{E}\right)$. These experiments were conducted in small aquaria (2.6 l) that were continuously provided with filtered seawater. They were maintained at $15^{\circ} \mathrm{C}$ in a constant temperature room and exposed to a PAR of $75 \mu \mathrm{M} \mathrm{m}^{-2} \mathrm{~s}^{-1}$ for $12 \mathrm{~h} \mathrm{~d}^{-1}$ (Master ECO TL-D cool white, Philips). An algal fresh weight of $3 \mathrm{~g}$ - either G. vermiculophylla or $F$. vesiculosus or both species in equal amounts - was incubated under such conditions with and without potential grazers (6 Idotea balthica, 10 Littorina sp., or 32 Gammarus sp.). After 1 wk the algal weight was quantified by weighing, and the difference between growth controls and treatments indicated the amount of biomass that had been consumed by grazers. The Mann-Whitney $U$-test and the Wilcoxon test were used in order to test the consumption rates of grazers in nochoice and 2-way-choice experiments, respectively, for significant differences $(p=0.05)$.

\section{RESULTS}

\section{Distribution of Gracilaria vermiculophylla}

Between Flensburg and Warnemünde, populations consisting of $>3$ separate fragments of $G$. vermiculophylla were only detected in the Kiel Fjord. Fragments cast ashore were occasionally found on a coastal range extending $75 \mathrm{~km}$ east of Kiel. Three largely decomposed fragments suspected to be G. vermiculophylla were once detected in Boltenhagen $\left(53^{\circ} 59^{\prime} \mathrm{N}\right.$, $\left.11^{\circ} 13^{\prime} \mathrm{E}\right)$, approximately $250 \mathrm{~km}$ east of Kiel (Fig. 2A). Their identity could not be confirmed, due to their poor condition. In the Kiel Fjord, G. vermiculophylla was particularly abundant in shallow and sheltered waters. Between 2006 and 2007 ground coverage in the Kiel Fjord increased in most observation areas - on average by a factor of approximately 3 (data not shown)and 2 of 7 areas were newly invaded. A particularly large population was present on the west shore of inner Kiel Fjord (Fig. 2B). The most dense part of this population-covering 50 to $100 \%$ of the groundincreased in size from 0.3 ha in 2005 to 1 ha in 2006. In 2007, it covered approximately 2.7 ha, which was most of the available sea ground shallower than $2 \mathrm{~m}$ in this area. Ground coverage at the periphery of this population decreased with increasing depth, and only a few small individuals were detected in water depths of $5 \mathrm{~m}$ or more. 


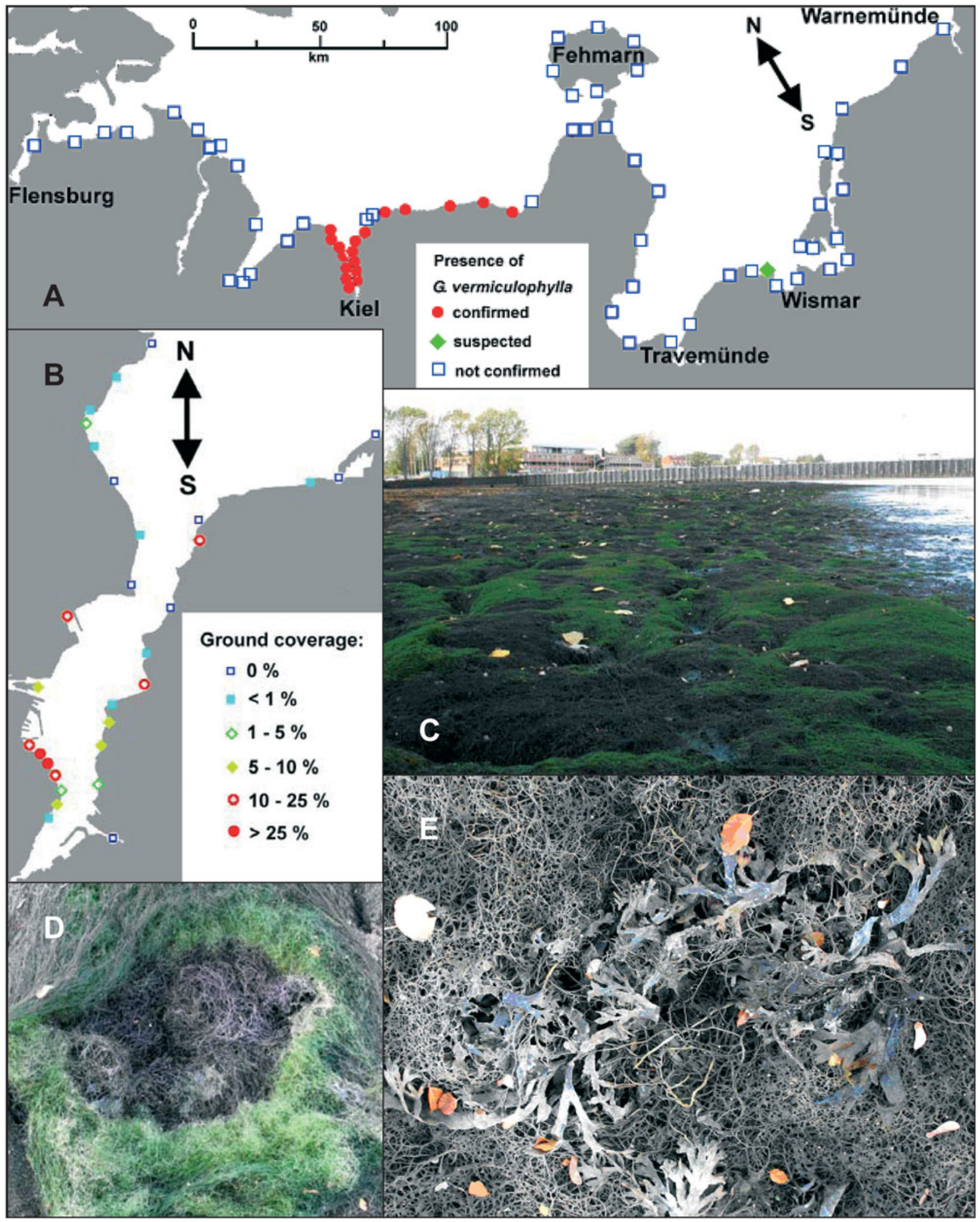

Fig. 2. Gracilaria vermiculophylla. (A) Distribution between Flensburg and Warnemünde until 2007. (B) Distribution and density in 2007 in Kiel Fjord. (C) Mat overgrown in part by Chaetomorpha linum (26 October 2006). (D) Detail of mat in (C), layer of C. linum has been locally removed. (E) Individuals of Fucus vesiculosus overgrown by G. vermiculophylla 
Sporogenic Gracilaria vermiculophylla or individuals attached to stones-and thus grown up from spores - were occasionally detected in the outer Kiel Fjord. In the inner Kiel Fjord G. vermiculophylla largely grows unattached, lying on the sea floor irrespective of the substrate type. Even the most dense populations were only loosely attached to the ground. They consisted of up to $45 \mathrm{~cm}$ thick mats of entangled individuals that covered up to several hundred square meters of ground. The basis of such mats was often decaying, at the same time the upper layer of the mats continued to grow. From time to time G. vermiculophylla mats were overgrown by ephemeral filamentous algae such as Chaetomorpha linum (O.F. Müller) Kützing, which persisted for several weeks, indicating a relatively stable structure of the mats (Fig. 2C,D). In some locations the bladder wrack Fucus vesiculosus was overgrown by G. vermiculophylla mats (Fig. 2E).

\section{Growth in the sea}

In a growth experiment conducted in the inner Kiel Fjord, Gracilaria vermiculophylla grew primarily in summer. Between June 2006 and June 2007, growth was mainly observed before mid-September and after mid-April, when average rates of SR exceeded $3 \mathrm{kWh} \mathrm{m}^{-2} \mathrm{~d}^{-1}$ (Fig. 3). Maximal growth rates of 4 to $7 \% \mathrm{~d}^{-1}$ were observed in June and July and directly below the water surface. Extreme low tides, exposing G. vermiculophylla to air for extended time periods, usually resulted in losses of biomass. However, such dying of $G$. vermiculophylla was not observed in nature. For example, an extremely low tide in the Kiel Fjord on 26 to 27 October 2006 exposed substrates and organisms at water depths of 0.25 and $0.5 \mathrm{~m}$ below the mean sea surface level for 26 and 16 h to air, respectively (Fig. 2C). This event nearly completely killed isolated individuals of $G$. vermiculophylla that were experimentally exposed in net bags at both water depths (Fig. 3). In contrast, natural G. vermiculophylla mats at the same depth (Fig. 2C) largely survived this air exposure event, as could be observed during repeated visits to the site.

Growth rates of Gracilaria vermiculophylla at different water depths and at different times of the year were positively correlated with PAR at these depths and at these times (Fig. 4A) $(r=0.71, p<0.0001)$. Directly below the water surface $(0.25 \mathrm{~m}$ below the mean sea surface), growth was better correlated with SR above the water surface $(r=0.71, p<0001$; Fig. 4B) than with mean water temperature $(\mathrm{r}=0.45, \mathrm{p}<0.0001$; Fig. $4 \mathrm{C})$. No or little growth was observed at this water depth when SR above the surface was $<3.5 \mathrm{kWh} \mathrm{m}^{-2} \mathrm{~d}^{-1}$ (Fig. 4C), or PAR was below the surface was $<130 \mu \mathrm{mol}$
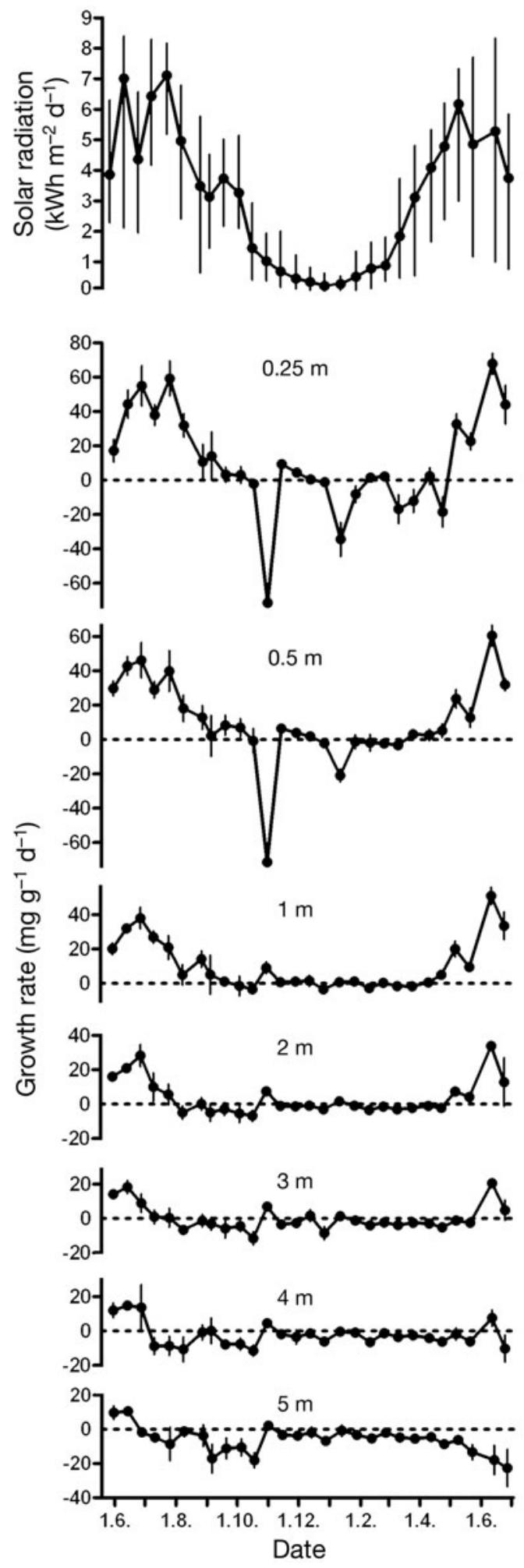

Fig. 3. Gracilaria vermiculophylla. Mean ( \pm range) daily insolation above the water surface and mean growth $( \pm 95 \% \mathrm{CI}$, $\mathrm{n}=6$ ) at 7 water depths between 0.25 and $5 \mathrm{~m}$ below the mean sea surface level in Kiel Fjord, between June 2006 June 2007 
A Water depth: 0.25 to $5 \mathrm{~m}$

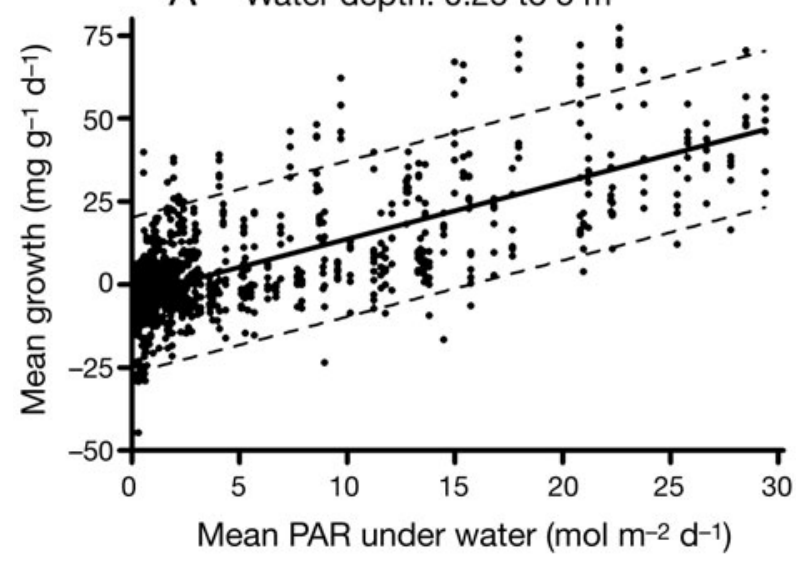

C Water depth: $0.25 \mathrm{~m}$

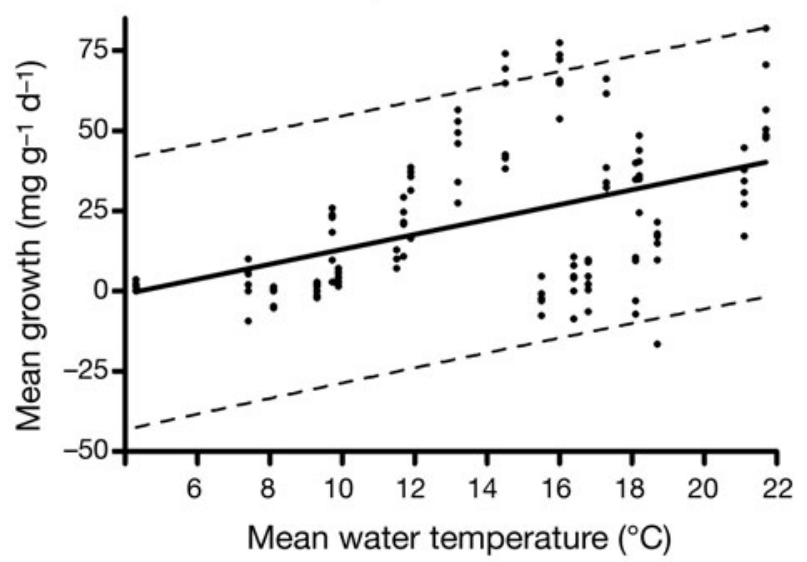

B Water depth: $0.25 \mathrm{~m}$

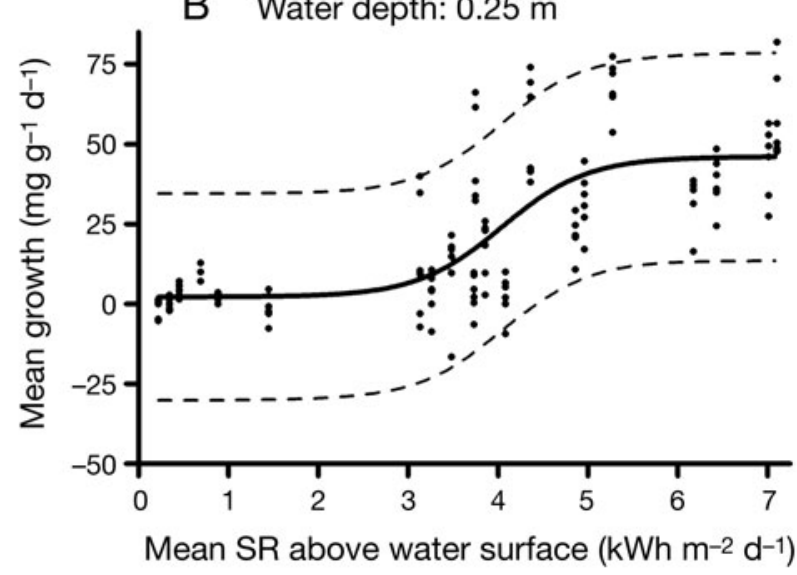

D Water depth: $5 \mathrm{~m}$

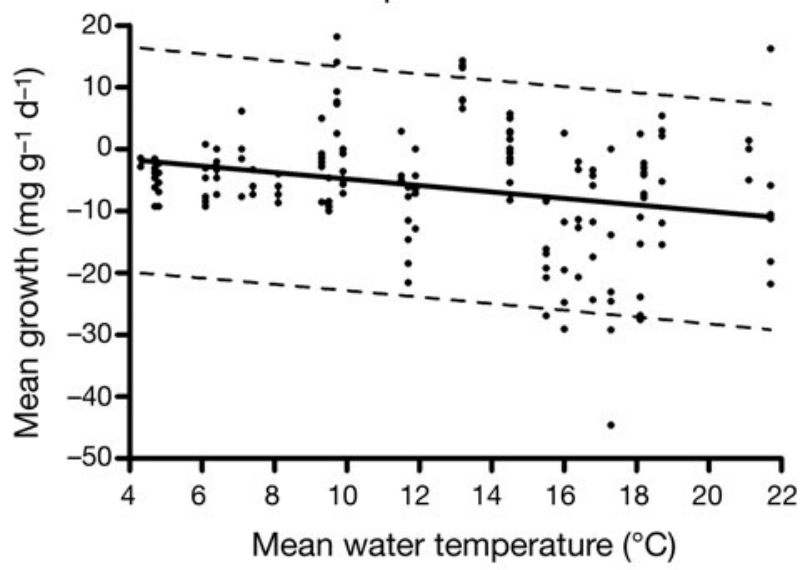

Fig. 4. Gracilaria vermiculophylla. Effects of sunlight and water temperature in the Kiel Fjord on growth. (A) the ratio between growth at all water depths between 0.25 and $5 \mathrm{~m}$ below mean sea level and photosynthetically active radiation (PAR) at these water depths, $(\mathrm{B}, \mathrm{C})$ the ratios between growth at $0.25 \mathrm{~m}$ water depth and solar radiation $(\mathrm{SR} ; \mathrm{B})$ and water temperature $(\mathrm{C})$, and (D) the ratio between growth at $5 \mathrm{~m}$ water depth and water temperature. Lines indicate best fitting logistic (B) and linear

$(\mathrm{A}, \mathrm{C}, \mathrm{D})$ functions with $95 \%$ prediction intervals

$\mathrm{m}^{-2} \mathrm{~s}^{-1}$. Increasing water depth resulted, not only in decreasing growth, but also in decreasing correlations of light availability and growth. At $5 \mathrm{~m}$ below the mean sea surface level, growth was negatively correlated with water temperature ( $\mathrm{r}=-0.276, \mathrm{p}=0.0003$; Fig. 4D).

Gracilaria vermiculophylla that had previously been incubated for at least $14 \mathrm{~d}$ at different water depths did not differ significantly in the maximum yield of photosynthesis after adaptation to darkness (Kruskal-Wallis ANOVA, $p=0.05$; Fig. 5). Similarly, the photosynthetic yield in steady state during exposure to sunlight containing 210 to $390 \mu \mathrm{mol} \mathrm{m} \mathrm{m}^{-2} \mathrm{~s}^{-1}$ PAR was not significantly different in algae that had been adapted for 2 wk to a maximum PAR of $30 \mu \mathrm{mol} \mathrm{m} \mathrm{m}^{-2} \mathrm{~s}^{-1}$ at a water depth of $5 \mathrm{~m}$ below the mean sea level and algae that had been adapted to a maximum PAR of $650 \mu \mathrm{mol} \mathrm{m}{ }^{-2}$ $\mathrm{s}^{-1}$ at a water depth of $0.25 \mathrm{~m}$.

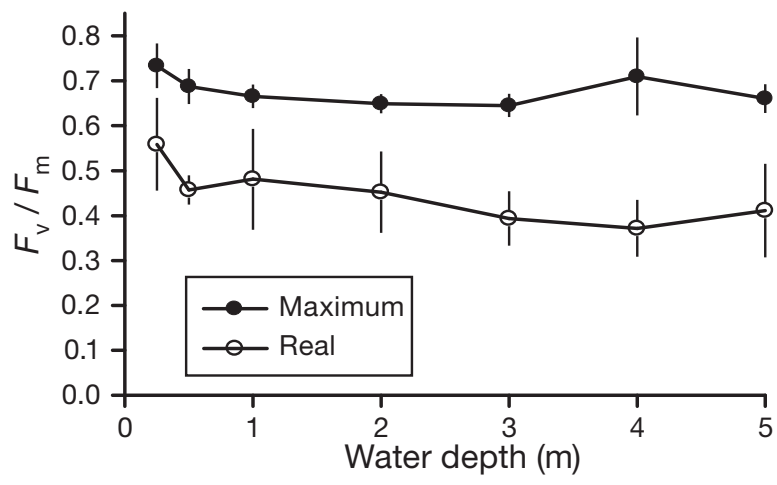

Fig. 5. Gracilaria vermiculophylla. Yield of photosynthesis $F_{\mathrm{v}} / F_{\mathrm{m}}$ in material from different water depths. Maximum yields were measured after 10 min of darkness adaptation, while real yields were measured in steady state during exposure to ambient light (directly below water surface); data are mean $\pm 95 \% \mathrm{CI}, \mathrm{n}=6$ 


\section{Effect of day length and salinity upon growth}

Under laboratory conditions, growth of Gracilaria vermiculophylla was slightly affected by day length when equal doses of PAR were applied: growth rates during permanent exposure to relatively low light were significantly lower than during exposure for 8 or $6 \mathrm{~h} \mathrm{~d}^{-1}$ to stronger light (Fig. 6).

During 3 growth experiments at different salinities conducted in spring, summer and autumn with continuous water exchange, the average salinity of the incoming seawater was 14.9. However, a higher average salinity was observed in autumn (16.2) than in spring and summer (14.2), which, accordingly, resulted in different salinities, when seawater was mixed with tap water. Additional salinity fluctuations were also observed during each of the 3 experiments (on average approximately \pm 1 ). During all 3 experiments, growth of Gracilaria vermiculophylla in aquaria supplied with $100 \%$ seawater was similar to growth in the sea, while diluted seawater sometimes caused significant growth reductions (Fig. 7). Particularly pronounced effects were observed in summer. For example, a seawater content of $5 \%$ caused the death of all algal biomass within $2 \mathrm{wk}$ in summer (mid-May to the end of June; average salinity: 1.0), while such death was neither observed during the $6 \mathrm{wk}$ in spring (mid-March to the end of April; 0.6) nor during the 4 wk in autumn (mid-September to mid-October; 1.5) (Fig. 7). In summer, significantly more growth of G. vermiculophylla was observed during the 6 wk in $100 \%$ seawater (salinity: 14.2) than in $80 \%$ seawater (10.2) or less (Kruskal-Wallis ANOVA and Nemenyi test, $\alpha=0.05$ ), and this difference was particularly pronounced after 4 and 6 wk of incubation (Fig. 7). In addition, growth in $20 \%$ seawater (4.7) was, after 4 and $6 \mathrm{wk}$, significantly lower than in $40 \%$ seawater (5.4) or more (Fig. 7). In contrast to summer, growth rates were not significantly different among salinities ranging from $20 \%$ (4.3) to $100 \%$ (14.2) seawater during $6 \mathrm{wk}$ in spring (salinity range: 4.3 to 14.2 ) and $4 \mathrm{wk}$ in autumn (salinity range: 4.3 to 16.2 ). Of the invertebrates that were incubated together with G. vermiculophylla, Littorina spp. and Idotea balthica did not survive in $40 \%$ seawater or less in spring, summer, or autumn, while Gammarus spp. died in $20 \%$ seawater or less in all 3 experiments.

Not surprisingly, the average water temperature was lower in the spring experiment $\left(7.4\right.$ to $\left.12.4^{\circ} \mathrm{C}\right)$ than in autumn $\left(13.7\right.$ to $15.3^{\circ} \mathrm{C}$ ) and summer (13.8 to $\left.17.9^{\circ} \mathrm{C}\right)$, and the highest water tempera- tures $\left(15.8\right.$ and $\left.17.9^{\circ} \mathrm{C}\right)$ were observed in the last $4 \mathrm{wk}$ of the summer experiment, when Gracilaria vermiculophylla responded particularly sensitively to low salinities. SR was lower in autumn (2.0 to $2.5 \mathrm{kWh} \mathrm{m}^{-2} \mathrm{~d}^{-1}$ ) than in spring ( 3.0 to $\left.4.7 \mathrm{kWh} \mathrm{m}^{-2} \mathrm{~d}^{-1}\right)$ and summer $(3.8$ to $5.3 \mathrm{kWh} \mathrm{m}^{-2} \mathrm{~d}^{-1}$ ).

\section{Associated animals and feeding antagonists}

The diversity of most of the functional and taxonomic groups of animals (all except omnivores, Isopoda and fishes) associated with Gracilaria vermiculophylla mats

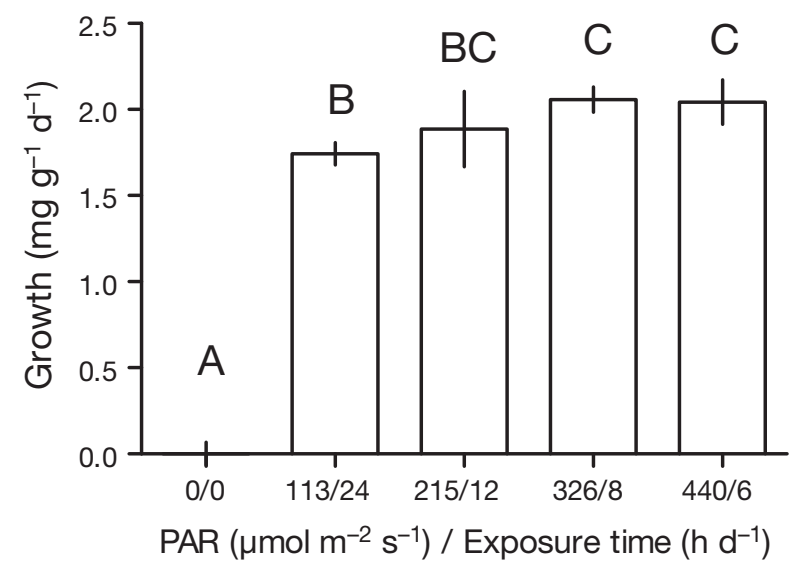

Fig. 6. Gracilaria vermiculophylla. Growth response when exposed over 1 wk to no light or to similar daily doses of photosynthetically active radiation (PAR, 9.3 to $9.7 \mathrm{~mol} \mathrm{~m}^{-2} \mathrm{~d}^{-1}$ ), but different combinations of light intensity and exposure time; data are mean $\pm 95 \% \mathrm{CI}, \mathrm{n}=5$. Data marked with different letters were significantly different (Kruskal-Wallis ANOVA and Nemenyi test, $\alpha=0.05$ )

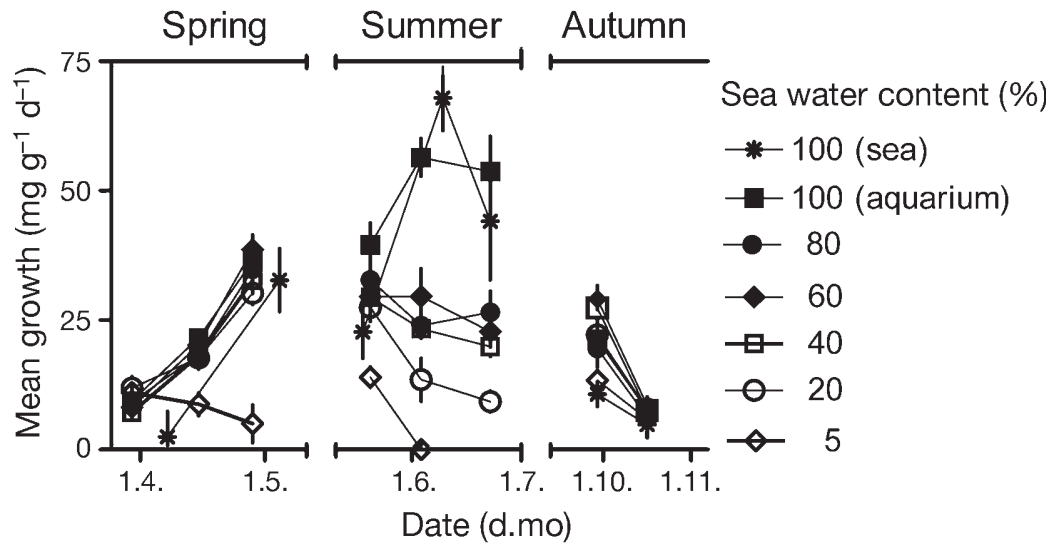

Fig. 7. Gracilaria vermiculophylla. Effect of different salinities on growth in 3 successive experiments conducted in spring, summer and autumn 2007. The average salinity of $100 \%$ seawater was 14.2 in spring and summer and 16.2 in autumn. Results obtained during the same time periods in the sea at a water depth of $0.25 \mathrm{~m}$ are included for comparison $\left({ }^{*}\right)$; data are mean $\pm 95 \% \mathrm{CI}_{\text {, }}$ $\mathrm{n}=2 \times 6=12\left({ }^{*}: \mathrm{n}=6\right)$ 
and with Fucus vesiculosus individuals growing within these mats was affected by the sampling time, in most cases with significantly less taxa in the relatively cold winter of 2005/2006 (surface water temperature range in the 2 mo preceding sampling: -1.1 to $4.6^{\circ} \mathrm{C}$ ) than in the relatively warm winter of 2006/2007 (surface water temperature range in the 2 mo preceding sampling: 2.8 to $7.6^{\circ} \mathrm{C}$ ) or in the summer of 2006 (Table 1). Total animals, omnivores, Bivalvia, Isopoda and Amphipoda were overall more diverse on $G$. vermiculophylla than on $F$. vesiculosus (Table 1). This difference was stronger or only present in winter (February 2006 and/or February 2007) and the diversity was therefore subject to significant interactive effects of season and associated alga (Table 1).

Seasonal differences were also observed in the density of most functional groups and taxa that were associated with the 2 algae (all except Gammarus salinus, omnivores and Idotea balthica; Table 2), with particularly low densities in February 2006. G. salinus was nearly exclusively detected on Gracilaria vermiculophylla. Overall, higher densities of Gammarus spp., I. balthica, omnivores and various mussels were also detected on G. vermiculophylla (Table 2). Similar to the diversity, the density of associated animals often differed among the 2 algal species in winter, but not in summer, and was subject to significant interactive effects of season and alga (Table 2). For example, $I$. balthica was, in winter, exclusively present on G. vermiculophylla, while Pomatoschistus pictus was only detected in summer and with G. vermiculophylla. Larvae of filter feeders such as Mya arenaria and Cerastoderma lamarckii settled preferentially on G. vermiculophylla, but did not persist on this alga until summer.

Of the animals associated with Gracilaria vermiculophylla and known as consumers of macroalgae, only Littorina spp., Idotea balthica and Gammarus spp. were relatively abundant and therefore considered to be potentially important grazers. No-choicefeeding trials revealed that all 3 have the capacity to feed on $G$. vermiculophylla (Fig. 8). Both in summer and winter, the largest amounts were ingested by I. balthica. However, I. balthica consumed more Fucus vesiculosus in nochoice assays, and this preference was confirmed when $G$. vermiculophylla and $F$. vesiculosus were offered together in 2-way-choice assays. A clear preference for $F$. vesiculosus was also observed in a 2-way-choice assay with Littorina spp. in winter, but not in summer. Gammarus spp. only consumed significant amounts of $G$. vermiculophylla.

\section{DISCUSSION}

Within 1 yr of survey, Gracilaria vermiculophylla clearly increased on a local scale within the Kiel Fjord. In contrast with this - and also in contrast with the marked spreading of $G$. vermiculophylla over a coastal range of $150 \mathrm{~km}$ around Göteborg (Sweden) within 2 yr (Nyberg 2007), little confirmed spreading was observed along the German Baltic coast. Fragments suspected to be G. vermiculophylla were, on one occasion, detected at a distance of $250 \mathrm{~km}$ east of Kiel, and it is not impossible that the alga was present at densities below the detection limit at other sites. However, it is also possible that the potential of G. vermiculophylla of being transported is not quite as high in the inner Baltic Sea as in environments with regular tidal currents. The alga predominantly lies loose, drifts and is capable of propagating by fragmentation, but it has no great buoyancy, which limits the distance that can be overcome by drifting. The global spreading of G. vermiculophylla has been suspected to result from its association with oysters (Rueness 2005, Thomsen et al. 2007), but cultivation of mollusks has little economic importance in the Baltic Sea. G. vermiculophylla does not usually grow on ship hulls (which would increase the risk of anthropogenic dispersal). Moreover, attachment of $G$. vermiculophylla to hard substrates largely depends on the formation of spores, which so far happens relatively rarely in the Kiel Fjord. The future long-distance spreading of $G$. vermiculophylla into the Baltic Sea may, therefore, rely on entanglement with boat propellers or anchors, fishing gear, etc., or on transport with ballast water and could result in a patchy rather than a closed distribution area during the next decades.

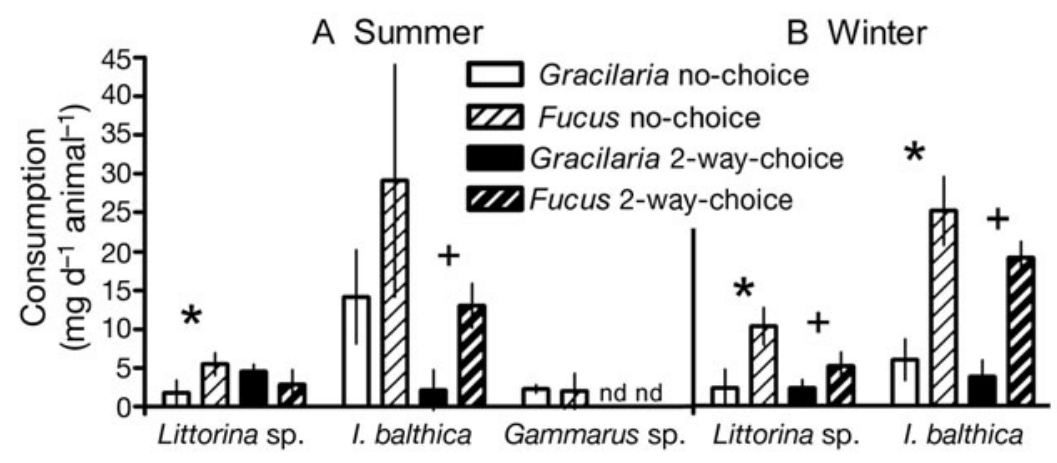

Fig. 8. Gracilaria vermiculophylla and Fucus vesiculosus. Consumption in: (A) summer and (B) winter by 3 different grazers. The algae were offered either separately (no-choice assay) or together (2-way-choice assay). Significantly different consumption rates of $G$. vermiculophylla and $F$. vesiculosus in the same season by the same grazer are marked by asterisks (no-choice assays, Mann-Whitney $U$-test, $\alpha=0.05$ ) and crosses (2-way choice assays, Wilcoxon test, $\alpha=0.05$ ); data are mean $\pm 95 \% \mathrm{CI}, \mathrm{n}=8$. nd $=$ no data 

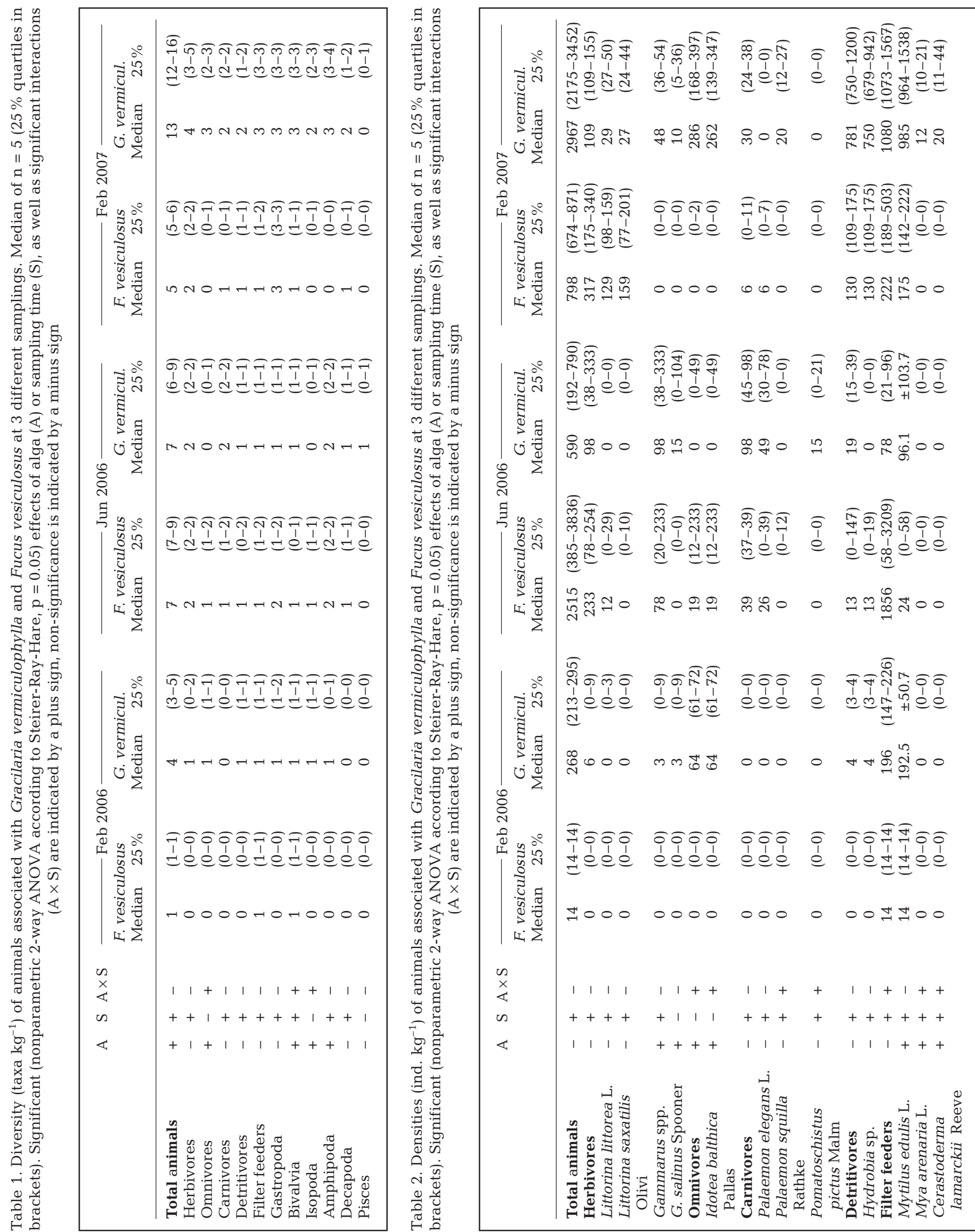
In the Kiel Fjord, with a maximum depth of $17 \mathrm{~m}$, single drifting individuals of Gracilaria vermiculophylla were detected in most locations, but large populations were only present in relatively sheltered and shallow areas. This may be a result of the drifting life history of the alga. However, multiplication of the yields and losses of biomass observed in 2006/2007 during experimental exposure of $G$. vermiculophylla in the sea shows that net growth is impossible long term at water depths of $3 \mathrm{~m}$ or more below the mean sea surface level (Table 3). In contrast, the annual average of daily growth at the first $2 \mathrm{~m}$ below the mean sea surface level was $18.45 \mathrm{mg} \mathrm{g}^{-1}$ and nearly 80 -fold biomass increases per year are possible in shallow water as long as G. vermiculophylla survives extremely low tides, which was usually the case in 2006/2007 (Table 3). The peak growth rates obtained at a water depth of $0.25 \mathrm{~m}$ reach approximately $30 \%$ of the maximal growth rates observed with $G$. vermiculophylla under optimized laboratory conditions (Raikar et al. 2001). At $5 \mathrm{~m}$ below the mean sea surface level, $84 \%$ of the G. vermiculophylla biomass exposed degraded within 1 yr (Table 3). Single individuals were occasionally detected in deeper water, but they probably drifted to these regions after they had grown up in shallower water. Thalli of G. vermiculophylla that are kept in insufficient light conditions may survive for long periods of time (Rueness 2005, Nyberg 2007, Thomsen et al. 2007). The loss of algal biomass at water depths below $3 \mathrm{~m}$ that was observed in our experiments indicates that $G$. vermiculophylla will nonetheless eventually be degraded in nature. At a depth of $5 \mathrm{~m}$, the loss of biomass increased with increasing water temperature, suggesting that it was due to biological processes such as grazing or respiration, rather than to mechanical damage. The order of magnitude of biomass drifting to depths below the light compensation point is difficult to estimate, but it may be considerable: G. vermiculo-

Table 3. Gracilaria vermiculophylla. Annual growth in the Kiel Fjord at different water depths. Data are based upon multiplication of successive relative increases or decreases of biomass observed during biweekly intervals over 1 yr (see Fig. 2). Data in brackets were calculated without consideration of biomass losses due to extremely low tides; data are mean $\pm \mathrm{SD}, \mathrm{n}=6$

\begin{tabular}{|cc|}
\hline $\begin{array}{c}\text { Water depth below } \\
\text { mean sea level }(\mathrm{m})\end{array}$ & $\begin{array}{c}\text { Annual growth } \\
\left(\mathrm{g} \mathrm{g}^{-1} \mathrm{yr}^{-1}\right)\end{array}$ \\
\hline 0.25 & $-0.996 \pm 0.003(79.7 \pm 58.4)$ \\
0.5 & $-0.99 \pm 0.01(36.1 \pm 28.1)$ \\
1 & $12.0 \pm 5.5$ \\
2 & $1.95 \pm 0.56$ \\
3 & $-0.17 \pm 0.40$ \\
4 & $-0.52 \pm 0.25$ \\
5 & $-0.84 \pm 0.06$ \\
\hline
\end{tabular}

phylla, experimentally exposed in situ, on average produced an 18.5-fold increase of biomass in the first $2 \mathrm{~m}$ below mean sea surface level, while the size of natural populations in the Kiel Fjord was only estimated to increase by a factor of 3 . Increases in weight and in ground coverage are obviously difficult to compare, but the discrepancy must at least in part be due to loss of biomass to deeper waters.

Our study indicates that only a few potential consumer species are associated with Gracilaria vermiculophylla in the Kiel Fjord at numbers high enough to cause significant biomass loss. Multiplication of the numbers of individuals that were detected on the alga with the amounts of algal biomass that were consumed per individual and day in feeding trials allows an estimation of biomass consumption in nature. According to this calculation of each gram of G. vermiculophylla in June 2006 approximately $2 \mathrm{mg} \mathrm{d}^{-1}$ were consumed. At the same time growth rates in the sea reached up to $60 \mathrm{mg} \mathrm{g}^{-1} \mathrm{~d}^{-1}$, indicating that an efficient control by grazers did not take place. In February 2006 - after a relatively cold winter - consumption was considerably less (approximately $0.4 \mathrm{mg} \mathrm{g}^{-1} \mathrm{~d}^{-1}$ ) than in June 2006, while it was nearly as high as in June after a mild winter in February 2007 (approximately $1.6 \mathrm{mg} \mathrm{g}^{-1} \mathrm{~d}^{-1}$ ). In situ growth rates of $G$. vermiculophylla during 2 successive time intervals of 2 wk in February 2007, at a water depth of $0.25 \mathrm{~m}$, were determined as $1.5 \mathrm{mg} \mathrm{g}^{-1}$ $\mathrm{d}^{-1}$ (95\% CI: 1.9) and $2.1 \mathrm{mg} \mathrm{g}^{-1} \mathrm{~d}^{-1}$ (95\% CI: 1.9), indicating that growth in nature was, at that time, approximately in the same order of magnitude as consumption. In conclusion, grazing may prevent $G$. vermiculophylla biomass in the Kiel Fjord from increasing in winter, but not in summer. In our experiments, grazers from the Kiel Fjord did not survive at salinities of approximately 5.5 or less and the effect of grazing upon G. vermiculophylla in areas with salinities $<8$ can, therefore, not be predicted based on our study.

In the Kiel Fjord growth of Gracilaria vermiculophylla is limited by the availability of light. This is indicated by the facts that highest growth rates were obtained directly below the water surface and that peak growth was observed in summer. Further, exposure of low light-adapted G. vermiculophylla to nearly maximum SR in mid-summer and at noon did not result in a significant inhibition of photosynthesis. G. vermiculophylla is obviously capable of coping with much stronger light intensities, which is also indicated by its distribution in the subtropics (Terada \& Yamamoto 2002). Growth of G. vermiculophylla directly below the water surface was better correlated with PAR than with water temperature, suggesting that the absence of growth in winter resulted primarily from a lack of light, rather than from low temperature. Our results 
also suggest that the growth inhibition in winter is not due to a day length effect: $G$. vermiculophylla grew slightly better under short-day than under long-day conditions, when it was provided with the same total amount of PAR.

In the sea and at a water depth of $0.25 \mathrm{~m}$ below the mean surface level, Gracilaria vermiculophylla was capable of growing, when SR above the water surface exceeded an average level of approximately $3.5 \mathrm{kWh}$ $\mathrm{m}^{-2} \mathrm{~d}^{-1}$. According to the Surface Meteorology and Solar Energy (SSE)-Model of NASA (Chandler et al. 2004) such conditions are below the long-term average given for all parts of the Baltic Sea from May to August and for all parts except the northern Bothnian Sea also in April. Our results indicate that G. vermiculophylla grows somewhat less when it is exposed for long time periods to low light than when it is exposed for short periods to high light. A growth reduction of up to $15 \%$ due to less intense SR may, therefore, be expected in the northern part of the Baltic Sea. Nonetheless, sufficient amounts of SR should be available in all parts of the Baltic Sea to sustain growth of G. vermiculophylla.

Marked effects of salinity on survival and growth performance were observed in our experiments, suggesting that this factor rather than insolation may limit the future spread of Gracilaria vermiculophylla in the Baltic Sea. The growth optimum of $G$. vermiculophylla has been determined in different studies to lie between salinities of 10 and 35 (Yokoya et al. 1999), between 10 and 20 (Rueness 2005) and at 15 (Raikar et al. 2001). Following this information the salinity in Kiel Fjord (13 to 17) and adjacent waters is optimal for the growth of $G$. vermiculophylla and further spreading into the Baltic Sea should confront it with successively less favorable salinities.

Yokoya et al. (1999) and Nyberg (2007) reported that Gracilaria vermiculophylla is capable of growing at salinities of 5 and 2, respectively. In our study, survival and even slow growth were possible at salinities as low as 0.5 and 1.6, although only in spring and autumn. Interestingly, G. vermiculophylla was more responsive to different salinities in summer than in spring or autumn, with reduced growth at 10.2, very reduced growth at 4.7 and incapacity to survive at 1 . The ultimate cause for this seasonally variable susceptibility remains unclear. However, it is reminiscent of the increasing sensitivity of $G$. vermiculophylla toward high salinities during a water temperature increase from 11.5 to $20^{\circ} \mathrm{C}$ (Rueness 2005). A similar effect of temperature on the sensitivity of $G$. vermiculophylla to low salinities may explain our observations: particularly high sensitivity toward low salinity was detected in periods when the water temperature exceeded $15.3^{\circ} \mathrm{C}$.
Under present salinity conditions, Gracilaria vermiculophylla should find optimal conditions with maximum growth rates in summer in the Belt Sea. Good growth with reduced peak rates in summer should also be possible in most parts of the inner Baltic, where salinities do not usually fall below 5.5. The performance of G. vermiculophylla in the Bothnian Gulf and the inner Gulf of Finland will probably be severely reduced, since water temperatures in summer must be expected to increase the algal sensitivity toward the prevailing low salinities.

Our observations suggest that Gracilaria vermiculophylla has the potential to modify certain habitats in the Baltic Sea, for example, as a competitor of other macrophytes. In the Kiel Fjord and adjacent waters sheltered shallow environments are until now typically inhabited by Fucus vesiculosus and other Fucus species, when hard bottom substrate is available. However, as in other regions of the Baltic Sea, Fucus spp. generally perform better in wave-exposed areas, which has been attributed to reduced recruitment success on substrates that are covered by silt or filamentous algae (Berger et al. 2003, Isaeus 2004). Coverage of hard substrate by drifting or attached G. vermiculophylla may, however, interfere with the settlement of Fucus spp. Moreover, our preliminary evidence indicates that $G$. vermiculophylla has the capacity to overgrow and probably shade $F$. vesiculosus.

Gracilaria vermiculophylla is not restricted to hard bottom substrates. Therefore, it also has a potential to modify soft-bottom communities, which dominate in the Kiel Fjord and adjacent waters. Seagrass (Zostera sp.) beds typically develop in water depths between 1 and $5 \mathrm{~m}$ below sea surface level in the western Baltic (authors' per. obs.). Therefore, they may overlap with the lower distribution range of $G$. vermiculophylla. A first settlement of $G$. vermiculophylla individuals in seagrass beds in the Kiel Fjord was observed in 2006. During the first year, we could not observe obvious effects on the seagrass (M. Wahl pers. obs.), which may be due to the relatively low density of the invader. It has been shown that intermediate amounts of benthic drift algae may add resources and increase the habitat complexity of otherwise bare soft bottom (Raffaelli et al. 1998, Norkko et al. 2000), causing the diversity and density of infauna and epifauna to increase (Bolam et al. 2000, Rossi \& Underwood 2002). In contrast, extended closed macroalgal mats may cause oxygen deficiency and subsequent changes of infauna (Norkko \& Bonsdorff 1996a,b). Such effects may potentially also be caused by $G$. vermiculophylla. During the summer of 2007, the sediments under extended G. vermiculophylla mats in Kiel Fjord often appeared hypoxic. These oxygen depletion events were probably due to excessive input of decomposing organic 
matter. However, it is unknown whether they had occurred before $G$. vermiculophylla arrived.

Seagrass beds and Fucus spp. belts in the Baltic Sea are known to be essential nursery grounds for invertebrates and fish (Anders \& Möller 1988, Beck et al. 2001, Worm \& Karez 2002, Moore \& Short 2006, Rönnbäck et al. 2007). However, in our experiments, the diversity and density of such organisms in Gracilaria vermiculophylla mats were similar or higher than on Fucus vesiculosus. Apparently, G. vermiculophylla has the capacity to deliver some ecological services that are provided by Fucus spp. Interestingly, the main mesograzer of F. vesiculosus in the Kiel Fjord (Idotea balthica) also uses $G$. vermiculophylla as a refuge in winter. This choice is not due to feeding preferences, since $I$. balthica in all seasons preferentially fed on $F$. vesiculosus rather than on $G$. vermiculophylla. If the presence of $G$. vermiculophylla increases the abundance of isopods by providing suitable shelter, then individuals of $F$. vesiculosus in the close vicinity of $G$. vermiculophylla mats may experience increased consumption by I. balthica. Preferential grazing by I. balthica may result in the decline of $F$. vesiculosus relative to other seaweeds (Schaffelke et al. 1995, Engkvist et al. 2004). Mesograzers could, thus, modulate the competition between $G$. vermiculophylla and other seaweeds.

In conclusion, the performance of Gracilaria vermiculophylla in different parts of the Baltic depends on the highly complex, interactive effects of salinity, light, temperature, competitors and consumers. It is difficult to predict exactly how fast and far G. vermiculophylla will spread, and how it will fare in the new locations, but the specific conditions in the Baltic appear particularly favorable. Based on our results, a future spread of $G$. vermiculophylla to the Åland archipelago $\left(60^{\circ} \mathrm{N}\right)$ and beyond into the southern Bothnian Gulf appears as probable and as possible, respectively. The alga may, therefore, be able to reach latitudes that are located $10^{\circ}$ or more further north than the northern edge of its natural distribution range (Island of Sacchalin, approximately $52^{\circ} \mathrm{N}$, as G. verrucosa; Skriptsova et al. 2001) and $2^{\circ}$ or more further north than the northern edge of its distribution range on the European Atlantic coast. As to the impact of such a potential invasion upon native communities, the effects may be not only be negative (e.g. loss of habitat for Fucus vesiculosus), but also positive (e.g. functional replacement of $F$. vesiculosus and gain of habitat for seaweed-associated organisms on soft-bottom substrates), which for other reasons has been receding for decades.

Acknowledgements. We thank the department for Marine Meteorology at IFM-GEOMAR for data on shortwave solar radiation, water temperature and tide gauge in Kiel Fjord. We also thank Mareike Hammann, Ammelie Heimholt and Kai Lohbeck for help with experiments.

\section{LITERATURE CITED}

Anders K, Möller H (1988) Seasonal fluctuations in macrobenthic fauna of the Fucus belt in Kiel Fjord (western Baltic Sea). Mar Ecol Prog Ser 103:141-150

Beck MW, Heck KL, Able KW, Childers DL and others (2001) The identification, conservation, and management of estuarine and marine nurseries for fish and invertebrates. BioScience 51:633-641

Bellorin AM, Oliveira MC, Oliveira EC (2004) Gracilaria vermiculophylla: a western Pacific species of Gracilariaceae (Rhodophyta) first recorded from the eastern Pacific. Phycol Res 52:69-79

> Berger R, Henriksson E, Kautsky L, Malm T (2003) Effects of filamentous algae and deposited matter on the survival of Fucus vesiculosus L. germlings in the Baltic Sea. Aquat Ecol 37:1-11

Bick A, Gosselck F (1985) Arbeitsschlüssel zur Bestimmung der Polychaeten der Ostsee. Mitt Zool Mus Berlin 61:171-272

> Bolam SG, Fernandes TF, Read P, Raffaelli D (2000) Effects of macroalgal mats on intertidal sandflats: an experimental study. J Exp Mar Biol Ecol 249:123-137

> Boudouresque CF, Verlaque M (2002) Biological pollution in the Mediterranean Sea: invasive versus introduced macrophytes. Mar Pollut Bull 44:32-38

Chandler WS, Whitlock CH, Stackhouse PW Jr (2004) NASA climatological data for renewable energy assessment. J Sol Energy Eng 126:945-949

Dytham C (2005) Choosing and using statistics: a biologist's guide, 2nd edn. Blackwell Publishing, Oxford

> Engkvist R, Malm T, Nilsson J (2004) Interaction between isopod grazing and wave action: a structuring force in macroalgal communities in the southern Baltic Sea. Aquat Ecol 38:403-413

Freshwater DW, Montgomery F, Greene JK, Hamner RM, Williams M, Whitfield PE (2006) Distribution and identification of an invasive Gracilaria species that is hampering commercial fishing operations in southeastern North Carolina, USA. Biol Invasiom 8:631-637

Jagnow B, Gosselck F (1987) Bestimmungschlüssel für die Gehäuseschnecken und Muscheln der Ostsee. Mitt Zool Mus Berlin 63:191-268

Isæus M, Malm T, Persson S, Svensson A (2004) Effects of filamentous algae and sediment on recruitment and survival of Fucus serratus (Phaephyceae) juveniles in the eutrophic Baltic Sea. Eur J Phycol 39:301-307

Köhn J, Gosselck F (1989) Bestimmungsschlüssel der Malakostraken der Ostsee. Mitt Zool Mus Berlin 65:3-114

Maggs CA, Stegenga H (1999) Red algal exotics on North Sea coasts. Helgol Meersunters 52:243-258

Meier HEM (2006) Baltic Sea climate in the late twenty-first century: a dynamical downscaling approach using two global models and two emission scenarios. Clim Dyn 27: $39-68$

Moore KA, Short FT (2006) Zostera: biology, ecology, and management. In: Larkum AWD, Orth RJ, Duarte CM (eds) Seagrasses: biology, ecology and conservation. Springer, Dordrecht, p 361-386

Nielsen R, Kristiansen A, Mathiesen L, Mathiesen H (1995) Distributional index of the benthic macroalgae of the Baltic Sea area. Acta Bot Fenn 155:1-55

> Norkko A, Bonsdorff E (1996a) Altered benthic prey-availability due to episodic oxygen deficiency caused by drifting algal mats. PSZNI: Mar Ecol 17:355-372

Norkko A, Bonsdorff E (1996b) Population responses of coastal zoobenthos to stress induced by drifting algal mats. Mar Ecol Prog Ser 140:141-151 
Norkko J, Bonsdorff E, Norkko A (2000) Drifting algal mats as an alternative habitat for benthic invertebrates: species specific responses to a transient resource. J Exp Mar Biol Ecol 248:79-104

Nyberg C (2007) Introduced marine macroalgae and habitat modifiers - their ecological role and significant attributes. PhD thesis, Göteborg University, Göteborg

Nyberg CD, Wallentinus I (2005) Can species traits be used to predict marine macroalgal introductions? Biol Invest 7: 265-279

Paavola M, Olenin S, Leppäkoski E (2005) Are invasive species most successful in habitats of low native species richness across European brackish water seas? Estuar Coast Shelf Sci 64:738-750

Raffaelli DG, Raven JA, Poole LJ (1998) Ecological impact of green macroalgal blooms. Oceanogr Mar Biol Ann Rev 36: 97-126

Raikar SV, Ima M, Fujita Y (2001) Effects of temperature, salinity and light intensity on the growth of Gracilaria spp. (Gracilariales, Rhodophyta) from Japan, Malaysia and India. Indian J Mar Sci 30:98-104

Rönnbäck P, Kautsky N, Pihl L, Troell M, Söderqvist T, Wennhage H (2007) Ecosystem goods and services from Swedish coastal habitats - identification, valuation, and implications of ecosystem shifts. Ambio 36:534-544

Rossi F, Underwood AJ (2002) Small-scale disturbance and increased nutrients as influences on intertidal macrobenthic assemblages: experimental burial of wrack in different intertidal environments. Mar Ecol Prog Ser 241: 29-39

Rueness J (2005) Life history and molecular sequences of Gracilaria vermiculophylla (Gracilariales, Rhodophyta), a new introduction to European waters. Phycologia 44: $120-128$

Schaffelke B, Evers D, Walhorn A (1995) Selective grazing of the isopod Idotea baltica between Fucus evanescens and

Editorial responsibility: Erik Bonsdorf, Åbo, Finland and Karsten Reise, Sylt, Germany
F. vesiculosus from Kiel Fjord (western Baltic). Mar Biol 124:215-218

Schories D, Selig U (2006) How to deal with alien species within the EU Water Framework Directive? Rostock Meeresbiol Beitr 15:147-158

Skriptsova AV, Titlyanova TV, Titlyanov EA (2001) Red algae of the genus Gracilaria in the south of the Russian far east. Russ J Mar Biol 27:538-542

Terada R, Yamamoto H (2002) Review of Gracilaria vermiculophylla and other species in Japan and Asia. In: Abbott IA (ed) Taxonomy of economic seaweeds, Vol 8. California Sea Grant College Program, University of California, La Jolla, CA, p 215-224

Thomsen MS, Gurgel CFD, Fredericq S, McGlathery KJ (2006) Gracilaria vermiculophylla (Rhodophyta, Gracilariales) in Hog Island Bay, Virginia: a cryptic alien and invasive macroalga and taxonomic correction. J Phycol 42: $139-141$

Thomsen MS, Staehr PA, Nyberg CD, Schwaerter S, KrauseJensen D, Silliman BR (2007) Gracilaria vermiculophylla (Ohmi) Papenfuss, 1967 (Rhodophyta, Gracilariaceae) in northern Europe, with emphasis on Danish conditions, and what to expect in the future. Aquatic Invasions 2: 83-94

$>$ Tseng CK, Xia BM (1999) On the Gracilaria in the western Pacific and the southeastern Asia region. Bot Mar 42: 209-217

Worm B, Karez R (2002) Competition, coexistence and diversity on rocky shores. In: Sommer U, Worm B (eds) Competiton and coexistence. Ecological Studies 161. SpringerVerlag, Heidelberg, p 133-164

Yokoya NS, Kakita H, Obika H, Kitamura T (1999) Effects of environmental factors and plant growth regulators on growth of the red alga Gracilaria vermiculophylla from Shikoku Island, Japan. Hydrobiologia 398/399: 339-347

Submitted: November 2, 2007; Accepted: July 11, 2008 Proofs received from author(s): August 26, 2008 